\title{
Similar but Different: Differences Hitherto Overlooked between Boleophthalmus pectinirostris and $B$. boddarti (Teleostei: Oxudercinae) in Indonesian Waters
}

\author{
Pormansyah', Muhammad Iqbal ${ }^{1 *}$, Syahputra Putra ${ }^{3}$, Arum Setiawan $^{3}$, Indra Yustian ${ }^{3}$ and Hilda Zulkifli ${ }^{3}$ \\ ${ }^{1}$ Faculty of Science, Sriwijaya University, Indonesia
}

${ }^{2}$ Department of Agriculture and Livestock, Indonesia

${ }^{3}$ Department of Biology, Sriwijaya University, Indonesia

Submission: January 22, 2021; Published: March 11, 2021

Corresponding author: Muhammad Iqbal, Biology Program, Faculty of Science, Sriwijaya University, Jalan Padang Selasa 524, Palembang, Sumatera Selatan 30129, Indonesia

\section{Abstract}

During 2006-2017, we made a series of observations of Boleophthalmus pectinirostris on the east coast of South Sumatra province and Bangka island, Sumatra, Indonesia. This species is very similar to $B$. boddarti, in size, external morphological characters and behaviour. In this paper, we discuss the external morphological differences between B. pectinirostris and B. boddarti. Records of B. pectinirostris in southern Sumatra increase the known distribution range of this species $800 \mathrm{~km}$ southwards, indicating that this species was previously confused with $B$. boddarti in Indonesian waters.

Keywords: Similar; Morphological characters; Oxudercidae; Boleophthalmus pectinirostris; Indonesia; Sumatra; Distribution

\section{Introduction}

The prospect of identifying gobies fills many people with more than a little consternation [1]. The systematics and phylogeny of the gobiies are acknowledged as being difficult, and the smaller gobiids, in particular, are often overlooked by collectors [2]. The external characters that are of most help in identifying gobies include the arrangement and shapes of the fins, the number of fin rays and soft fin spines, the number of branchiostegal rays (in the membrane under the gill cover), the extent of the gill opening, the kind of scales (cycloid or ctenoid) and their distribution on the body, the proportions of the head, the jaw shape and position of the jaw tips, the shape of the teeth and the arrangement of the lateral canals and sensory papillae on the head [1]. Some of them, the oxudercine gobies, are euryhaline fish that are typically found on tidal flats formed in creeks, estuaries, and coastal waters at low tide [3].

In a cladistic analysis of the Oxudercinae subfamily of the Gobiidae, based on osteological, eco-ethological and morphological characters [4], the three genera of oxudercine gobies (Boleophthalmus Valenciennes, 1837, Periophthalmus Bloch \& Schneider, 1801, and Periophthalmodon Bleeker, 1874), were grouped in the same clade with the following shared characteristics: the abductor superficialis muscle of the pectoral fin is divided into two sections (presumably aiding terrestrial locomotion); and the neurocranial cavities are anteriorly enlarged, with a curved frontal interorbital bridge which overlaps with the ethmoid bones $[4,5]$.

The species in these genera can move over land with considerable speed; and their eyes, placed on top of the head and capable of being elevated or retracted, are well adapted for vision in air [6]. With different degrees of taxonomic and gene sampling bias, molecular studies have provided phylogenetic reconstructions for oxudercine gobies that are inconsistent with morphological, osteological, and eco- ethological analyses $[7,8]$. Recent studies have found molecular evidence to support the 
division of the family Gobiidae into two major clades, recognized here as the families Oxudercidae (Gobionellidae, oxudercine gobies) and Gobiidae $[6,8,9]$.

The mudskipper genus Boleophthalmus Valenciennes, 1837, is one of amphibious gobies, distributed in tropical and temperate intertidal habitats of the Indo-Pacific region, from the Persian Gulf east to the Gulf of Papua, and from southern Japan south to northern Australia [5]. Six species are recognised within this genus: Boleophthalmus birdsong [4]; B. boddarti (Pallas, 1770); B. caeruleomaculatus McCulloch \& Waite, 1918; B. dussumieri Valenciénnes, 1837; B. pectinirostris (Linnaeus, 1758); and $B$. poti [5]. Two of these, B. boddarti and B. Pectinirostris, both have numerous small blue speckles, which become larger and more scattered on the flank and dorsum $[1,4,5,10,11]$, and are very similar in external morphological appearance.

A few specimens of Boleophthalmus pectinirostris were observed and photographed during 2006-2017, on the east coast of South Sumatra Province and Bangka Island, Sumatra, Indonesia. However, it is more appropriate to describe them as $B$. pectinirostris than as $B$. pectinirostris, because two allopatric populations of $B$. pectinirostris sensu lato are found on the western Pacific coast of East Asia and the strait of Malacca in Malaysia, and the species status of the Malaysian populations remain uncertain [12]. It is probable that the specimens found in southern Sumatra are the "Malaysian clade", and this species is in clear need of taxonomic revision. The similarity of B. pectinirostris and $B$. boddarti in size, external morphological characters and behaviour could be the reason why this species is apparently almost absent from Sumatran or Indonesian waters. These recent records increase the species' known distribution southwards by about $800 \mathrm{~km}$.

\section{Materials and Methods}

We observed and photographed individuals of Boleophthalmus pectinirostris during 2006-2017, at four locations on the east coast of South Sumatra province and Bangka island, Sumatra, Indonesia (Figure 1, Table 1). Ideally, for a new record, specimens should be collected, measured, fixed and preserved, and deposited in a museum. Unfortunately, we did not realize that the specimens might constitute new records until we checked our photos and investigated their morphological characters.

Table 1: Locations and dates on which individuals of Boleophthalmus pectinirostris were recorded in southern Sumatra and Bangka during 2006 to 2017 .

\begin{tabular}{|c|c|c|c|}
\hline No & Location & Coordinates & Observation Date \\
\hline 1 & $\begin{array}{l}\text { Between Sungai Apung and Solok Buntu, Banyuasin district, east } \\
\text { coast of South Sumatra province }\end{array}$ & $\begin{array}{l}2^{\circ} 12^{\prime} 36.1908^{\prime \prime} \mathrm{S} \\
104^{\circ} 53^{\prime} 35.4084^{\prime \prime} \mathrm{E}\end{array}$ & 21 August 2006 \\
\hline 2 & Sungsang, Banyuasin district, South Sumatra province & $\begin{array}{l}2^{\circ} 21^{\prime} 28.9872 " \mathrm{~S} \\
104^{\circ} 54^{\prime} 22.212^{\prime \prime} \mathrm{E} .\end{array}$ & 14 September 2012 \\
\hline 3 & $\begin{array}{c}\text { Tanjung Bunga beach, Air Itam village, Pangkal Pinang, Bangka } \\
\text { island }\end{array}$ & $\begin{array}{c}2^{\circ} 7^{\prime} 56.5428^{\prime \prime S} \\
106^{\circ} 10^{\prime} 51.3372^{\prime \prime} \mathrm{E}\end{array}$ & 16 December 2012 \\
\hline 4 & $\begin{array}{c}\text { Barong river, Banyuasin district, east coast of South Sumatra } \\
\text { province }\end{array}$ & $\begin{array}{l}2^{\circ} 11^{\prime} 45.0816^{\prime \prime} \mathrm{S} \\
104^{\circ} 53^{\prime} 57.5016^{\prime \prime} \mathrm{E}\end{array}$ & 8 September 2017 \\
\hline
\end{tabular}

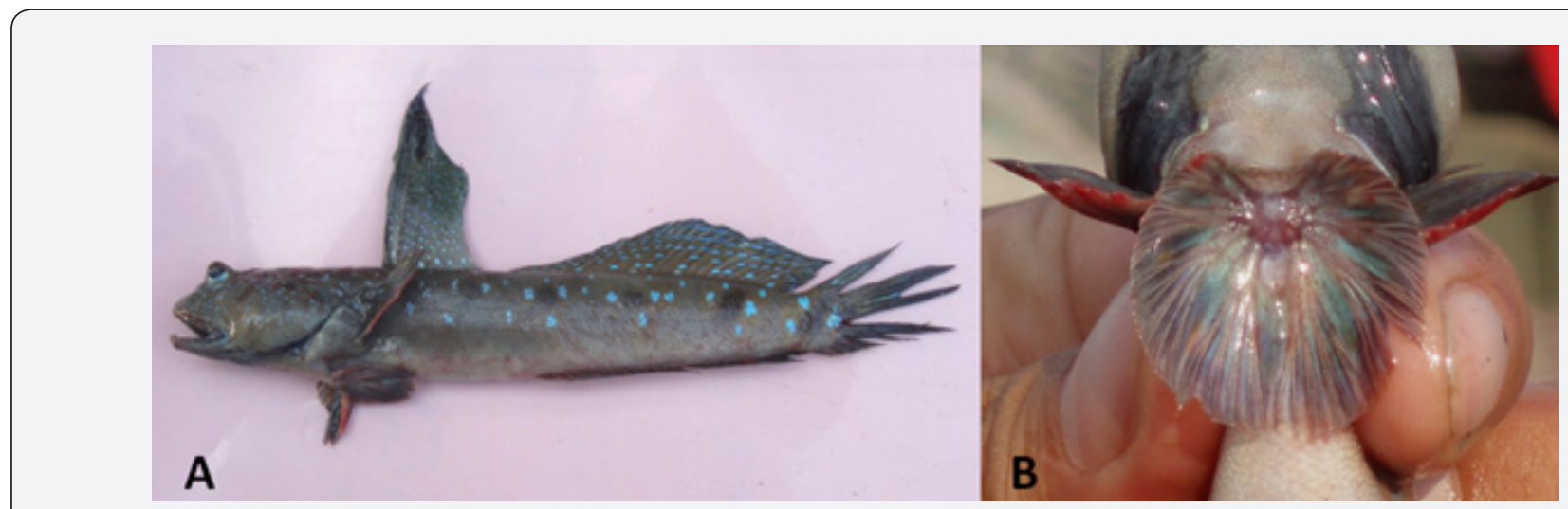

Figure 1: A. The specimen of B. pectinirostris caught by fishermen on 21 August 2008 on the east coast of South Sumatra province. B. Pelvic fins of $B$. pectinirostris (Photo: Muhammad lqbal).

\section{Results and Discussion}

Similar species to B. pectinirostris include large to medium mudskippers that occur in western Indonesian waters as summarised [13,14]: Boleopthalmus boddarti, Periopthalmodon schlosseri, Pn. septemradiatus, Periophthalmus argentilianus, P. chrysospilos, P. kalolo and P. malaccensis. Except B. boddarti, 
all of the above mudskippers can easily be distinguished by the absence of blue speckles on the body, from head to peduncle. Periopthalmodon schlosseri and Periophthalmus malaccensis exhibit blue speckles on the head, and P. septemradiatus on both head and flanks. Thus, within its range, B. pectinirostris is only likely to confused with $B$. boddarti, because both share small blue dots on the body. The principal features for field identification of B. pectinirostris and B. boddarti are summarised in Table 2 (Figure 2-4).

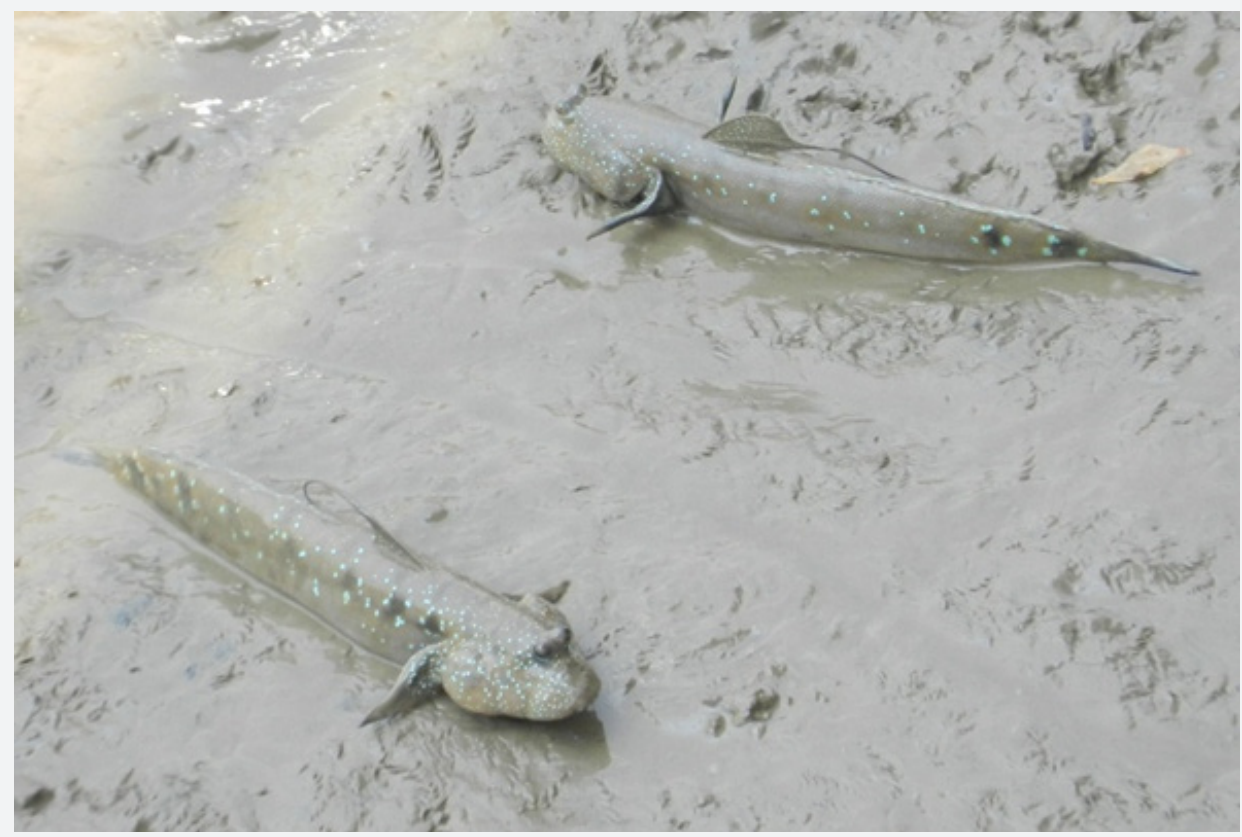

Figure 2: The specimens of Boleophthalmus pectinirostris on 14 September 2012 at Sungsang, South Sumatra province (Photo: Muhammad lqbal).

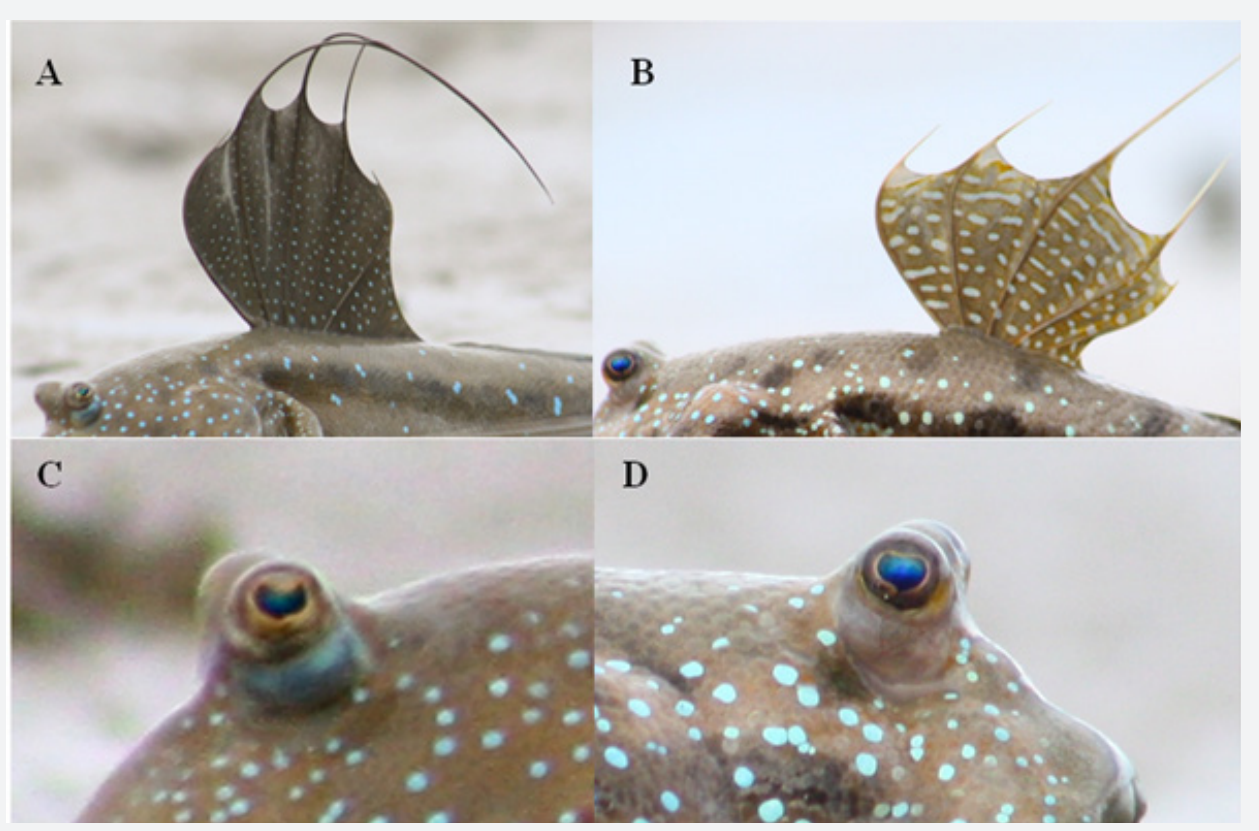

Figure 3: A. First dorsal fin of Boleophthalmus pectinirostris, with smaller blue spots; B. First dorsal fin of B. boddarti, brighter with larger blue spot, base is shorter; C. Base of eyes of are blue; D. Base of eyes of B. boddarti are greyish brown (Photo: Muhammad lqbal and Syahputra Putra). 


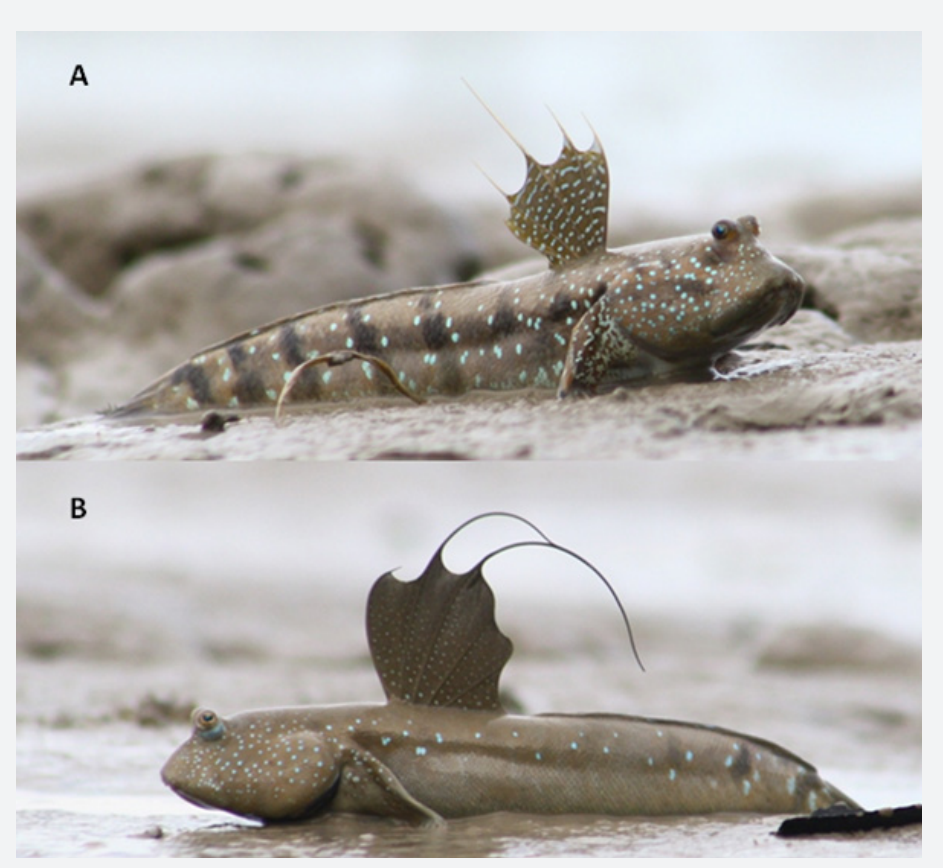

Figure 4: Lateral patterns on B. Boddarti and B. Pectinirostris in the same area on 16 December 2012 at Tanjung Bunga beach, Pangkal Pinang, Bangka island; (A) B. boddarti, the body is paler (grey to pale greyish), with 7 black diagonal bars on the side; 3-4 bars under the second dorsal fin reach the underparts; (B) Female of $B$. Pectinirostris, the body is grey-brown to blackish grey, with vertical sides saddle bars across the side but only reaching midlateral, expect one near peduncle reaching the underparts, it tends to be horizontal when exposed on the mudflats (Photo: Syahputra Putra).

The records. of $B$. pectinirostris in southern Sumatra since 2006 indicate that this species could previously have been overlooked in Indonesian waters. It is presumed that the similarity of this species with $B$. boddarti, which is sympatric and has much the same external morphological characters, is the reason why this species has been overlooked in the past. Furthermore, the fact that B. pectinirostris was not recorded previously in southern Sumatra (and also in Indonesian waters) could arise from a lack of local ichthyological experts able to separate this species from $B$. boddarti. To aid better identification, we share our experiences on how to separate $B$. pectinirostris and B. boddarti based on external morphological characters (Table 2).

Table 2. Summary of the principal features for field identification of $B$. pectinirostris and $B$. boddarti, based on our observations and on selected references $[1,3-5,11,12]$.

\begin{tabular}{|c|c|c|}
\hline Features & B. pectinirostris & B boddarti \\
\hline Overall appearance & $\begin{array}{l}\text { The body is slightly slimmer and darker, black to black- } \\
\text { ish grey (Figure 1A \& 4B) }\end{array}$ & $\begin{array}{l}\text { The body is quite a bit thicker and is paler, grey to pale greyish } \\
\text { (Figure 4A) }\end{array}$ \\
\hline Head & The base of the eyes is blue (Figure $3 \mathrm{~A}$ ) & $\begin{array}{c}\text { The base of the eyes is greyish brown, the blue spots on the head } \\
\text { are larger (Figure 3B) }\end{array}$ \\
\hline $\begin{array}{l}\text { First dorsal fin } \\
\text { (when open) }\end{array}$ & $\begin{array}{l}\text { Clearly darker with smaller blue spots or scattered sky- } \\
\text { blue spots (Figure 3A) }\end{array}$ & $\begin{array}{l}\text { Lighter color and with larger blue spots, bright yellow in smaller } \\
\text { specimens (Figure 3B) }\end{array}$ \\
\hline Lateral body & $\begin{array}{l}\text { Black diagonal vertical saddle bars across the side but } \\
\text { only reaching midlateral, except one near peduncle } \\
\text { reaching underpart; Length of caudal fin equal to or less } \\
\text { than } 22 \% \text { standard length (Figure 4B) }\end{array}$ & $\begin{array}{l}\text { Darker stripes that were clearly discernible from the dorsal to } \\
\text { ventral parts of the body; seven black diagonal vertical saddle bars } \\
\text { across the side, where 3-4 bars under second dorsal fin are reach- } \\
\text { ing underpart, or dark saddle-like bars often extending below the } \\
\text { midline in the posterior third of the body (Figure 4A) }\end{array}$ \\
\hline
\end{tabular}

As other land gobies, B. pectinirostris is an amphibious mudskipper inhabiting mudflats at low tide [5]. The occurence of B. pectinirostris in Indonesia was recognised [11], based on studies of oxudercine gobies in Tebing Tinggi and Bengkalis island, Riau province [3], who previously identified it $B$. dussumieri, commenting "the difficulty of collecting specimens may explain why B. dussumieri has not been previously reported from areas where large numbers of the species are now known to occur". Due to the similarity of external morphological characters and behaviour, we are convinced that the lack of records of $B$. pectinirostris in Sumatra and possibly also on the Sunda shelf of western Indonesia arises from the confusion of $B$. pectinirostris with $B$. boddarti. Boleophthalmus boddarti is also an amphibious mudskipper inhabiting mudflats at at low tide and is distributed in Sumatra, Borneo and Sulawesi $[5,13,14]$. 
The recent records from southern Sumatra $\left(02^{\circ} \mathrm{S}\right)$ are the southernmost records of the known global distribution of $B$. pectinirostris [5,10,11]. However, further careful surveys of exposed mudflats near mangrove forest in other Sunda shelf areas (particularly southern Kalimantan or Java) could lead to the discovery of more populations of B. pectinirostris. We summarize the principal features of the external morphological characters of B. pectinirostris and B. boddarti to aid more accurate identification in the field (Table 2, Figure 5).

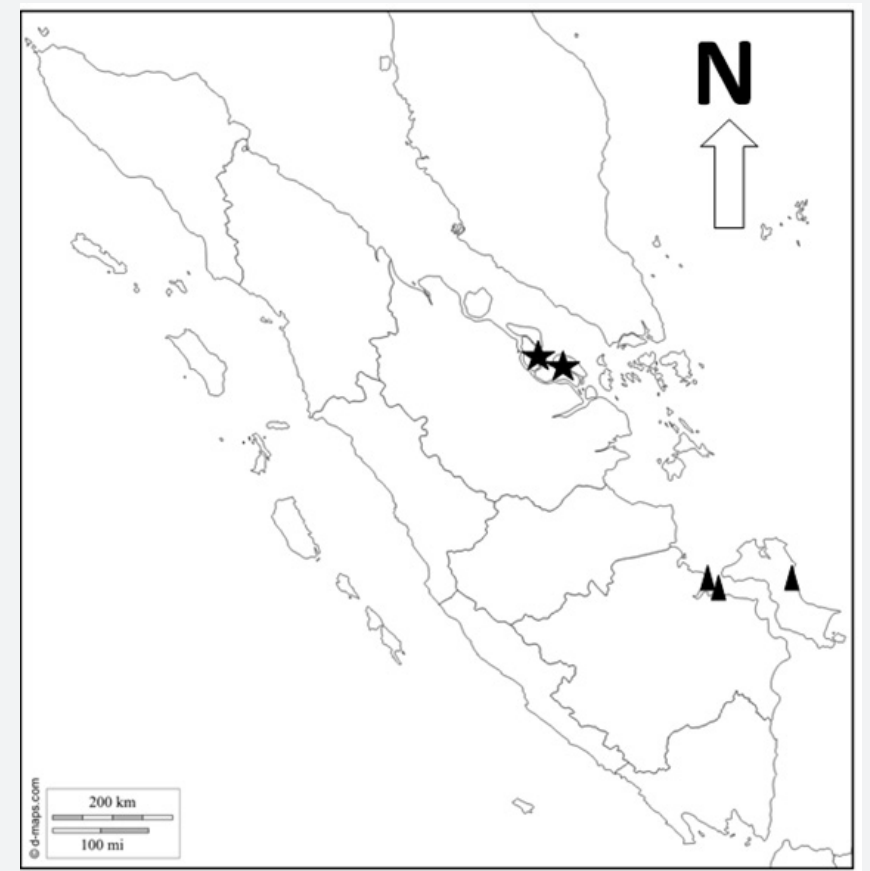

Figure 5: Location of Boleophthalmus pectinirostris records in Sumatra. Black stars show the previous record from Tebing Tinggi and Bengkalis Island, Riau Province; and black triangles show records during 2006-2017 in South Sumatra Province and Bangka island, Sumatra, Indonesia.

The finding of $B$. pectinirostris in the southern Sumatra is a significant distribution record for Indonesia (Figure 5). The first confirmed record of B. pectinirostris in Sumatra was reported from Tebing Tinggi Island, Riau Province [3,11]. It is more likely that it had not been reported before because the fish fauna of South Sumatran waters had not been sufficiently studied than the species has recently colonized the area. Recent work in South Sumatran waters show that local people know that a few species occur but no records of them have been published; these include Fluvitrygon oxyrhynchus, F. signifer, Urogymnus polylepis, Crossocheilus obscurus and Lobocheilos ixocheilos, Periophthalmodon septemradiatus and Periophthalmus variabilis [15-20].

\section{References}

1. Larson HK, Lim KKP (2005) A guide to gobies of Singapore, National Science Centre, Singapore.

2. Larson HK (2001) A revision of the gobiid fish genus Mugilogobius (Teleostei: Gobioidei), and its systematic placement. Records of the Western Australian Museum 62: 1-233.

3. Takita T, Agusnimar, Ali AB (1999) Distribution and habitat requirements of oxudercine gobies (Gobiidae: Oxudercinae) along the Straits of Malacca. Ichthyological Research 46(2): 131-138.

4. Murdy EO (1989) A taxonomic revision and cladistic analysis of the Oxudercine Gobies (Gobiidae: Oxudercinae). Records of the Australian Museum Supplement 11: 1-93.

5. Polgar, G, Jaafar Z, Konstantinidis P (2013) A new species of mudskipper, Boleophthalmus poti (Teleostei: Gobiidae: Oxudercinae) from the Gulf of Papua, Papua New Guinea, and a key to the genus. The Raffles Bulletin of Zoology 61(1): 311-321.

6. Nelson JS, Terry C, Grande TC, Wilson MVH (2016) Fishes of the world. In: ( $5^{\text {th }}$ Edn), John Wiley \& Sons, USA.

7. Agorreta A, Ruber L (2012) A standardized reanalysis of molecular phylogenetic hypotheses of Gobioidei. Systematics and Biodiversity 10: 375-390.

8. Agorreta A, san Mauro D, Schliewen U, van Tassell JL, Kovacic M, et al. (2013) Molecular phylogenetics of Gobioidei and phylogenetic placement of European gobies. Molecular Phylogenetics and Evolution 69: 619-633.

9. Thacker CE (2013) Phylogenetic placement of the European sand gobies in Gobionellidae and characterization of gobionellid lineages (Gobiiformes: Gobioidei). Zootaxa 3619: 369-382.

10. Polgar G (2014) The mudskipper. Available from: http://www. mudskipperit. (17 December 2017). 
11. Polgar G, Crosa G (2009) Multivariate characterization of the habitats of seven species of Malayan mudskippers (Gobiidae: Oxudercinae). Marine Biology 156(7): 1475-1486.

12. Chen H, Polgar G, Yin W, Fu C (2014) Cryptic species and evolutionary history of the Boleopthalmus pectinorostris complex along the Northwest Pacific coast. Acta Hydrobiologica Sinica 38(1): 75-86.

13. Kottelat M, Whitten AJ, Kartikasari SN, Wirjoatmodjo S (1993) Freshwater fishes of Western Indonesia and Sulawesi, Periplus, Hong Kong.

14. Pormansyah, Iqbal M, Arum S, Indra Y, Hilda Z (2019) A review of recent status on mudskippers (Oxudercine Gobies) in Indonesian waters. Oceanography \& Fisheries Open Access Journal 9(4): 001004.

15. Iqbal M, Yustian I (2016) Occurrence of the Giant Freshwater Stingray Urogymnus polylepis in Sumatra, Indonesia (Chondrichthyes: Dasyatidae). Ichthyological Exploration of Freshwaters 27(4): 333 336.
16. Iqbal M, Setiawan D, Ajiman (2018) New data on the distribution of the endangered white-edge freshwater whipray Fluvitrygon signifer (Chondrichthyes: Dasyatidae). Ichthyological Exploration of Freshwaters 28(2): 171-176.

17. Iqbal M, Setiawan A, Aprillia I, Isa M, Yustian I (2017b) First record of Lobocheilos ixocheilos Kottelat \& Tan, 2008 (Cypriniformes, Cyprinidae) in South Sumatra province, Indonesia. Check List 13(6): 931-933.

18. Iqbal M, Yustian I, Indriati W, Setiawan D, Setiawan A (2017c) Crossocheilus obscurus Tan \& Kottelat, 2009 (Teleostei, Cyprinidae) distribution extension and first record for Musi basin, South Sumatra, Indonesia. Check List 13(6): 1121-1124.

19. Iqbal M, Halim A, Adriani D, Pormansyah, Saputra RF (2018) Range extension of Periophthalmodon septemradiatus (Gobiidae) in southern Sumatra, Indonesia. Cybium 42(4): 376-378.

20. Setiawan A, Iqbal M, Priscillia B, Pormansyah, Setiawan D, et al. (2019) Linking a gap, First record of dusky-gilled mudskipper Periophthalmus variabilis Eggert, 1935 (Perciformes: Gobiidae) in southern Sumatra, Indonesia. Ecologica Montenegrina 24: 11-16.

\section{Your next submission with Juniper Publishers will reach you the below assets}

- Quality Editorial service

- Swift Peer Review

- Reprints availability

- E-prints Service

- Manuscript Podcast for convenient understanding

- Global attainment for your research

- Manuscript accessibility in different formats

( Pdf, E-pub, Full Text, Audio)

- Unceasing customer service

Track the below URL for one-step submission https://juniperpublishers.com/online-submission.php 